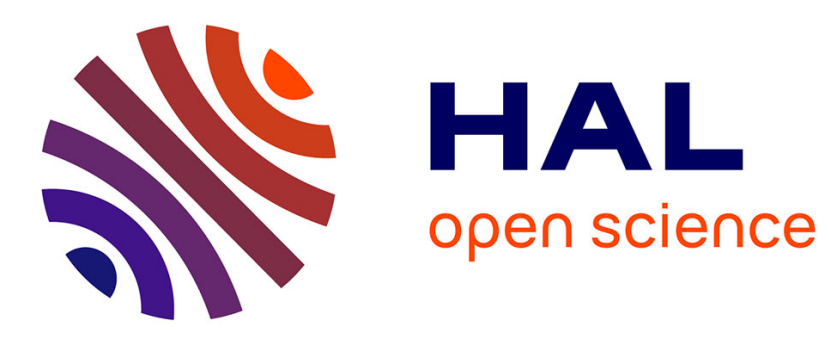

\title{
Topsoil as affected by dung deposition under resting places of red howler monkey (Alouatta seniculus)
}

Sandrine Pouvelle, François Feer, Jean-François Ponge

\section{To cite this version:}

Sandrine Pouvelle, François Feer, Jean-François Ponge. Topsoil as affected by dung deposition under resting places of red howler monkey (Alouatta seniculus). Pedosphere, 2008, 18 (6), pp.691-698. 10.1016/S1002-0160(08)60064-8 . hal-00495200

\section{HAL Id: hal-00495200 \\ https://hal.science/hal-00495200}

Submitted on 25 Jun 2010

HAL is a multi-disciplinary open access archive for the deposit and dissemination of scientific research documents, whether they are published or not. The documents may come from teaching and research institutions in France or abroad, or from public or private research centers.
L'archive ouverte pluridisciplinaire HAL, est destinée au dépôt et à la diffusion de documents scientifiques de niveau recherche, publiés ou non, émanant des établissements d'enseignement et de recherche français ou étrangers, des laboratoires publics ou privés. 
1 Date of submission of the revised version: January 29, 2008

2 Name of authors: Sandrine Pouvelle, François Feer, Jean-François Ponge

3 Affiliation: Muséum National d'Histoire Naturelle, CNRS UMR 7179, 4 avenue du Petit-

4 Château, 91800 Brunoy, France

5 Corresponding author: Jean-François Ponge, Tel.: +33 1 60479213, Fax: +33 1

6 60465009, E-mail: jean-francois.ponge@wanadoo.fr

7 Potential reviewers:

8 Dr Xingjun Tian, School of Life Science, Nanjing University, Nanjing 210093, People’s

9 Republic of China, E-mail: tianxj@nju.edu.cn

10 Dr Karel Klinka, University of British Columbia, Forest Sciences Centre \#3041, 2424

11 Main Mall, Vancouver, British Columbia V6T 1Z4, Canada, Tel.: +1 604822 3047, Fax:

$12+1604822$ 9102, E-mail: klinka@ interchg.ubc.ca

13 Dr Takeda Hiroshi, Laboratory of Forest Ecology, Division of Environmental Science and

14 Technology, Graduate School of Agricultural Sciences, Kyoto University, 606-8502 Sakio-

$15 \mathrm{Ku}, \quad$ Kyoto, Japan, Tel.: +81 757536080, Fax: +81 757536129, E-mail:

16 takedah@kais.kyoto-u.ac.jp

17 Type of contribution: Full-length paper

18 Complete title of the manuscript: Topsoil effects of dung deposition under red howler

19 monkey (Alouatta seniculus) resting places

20 Running title: Topsoil effects of dung deposition

$21 \quad$ Number of text pages: 16

22 Number of illustrations: 3 Figures and 1 Appendix 
1 Running Title: TOPSOIL EFFECTS OF DUNG DEPOSITION

2

3 Topsoil Effects of Dung Deposition under Red Howler Monkey (Alouatta

4 seniculus) Resting Places

5

S. POUVELLE, F. FEER and J.F. PONGE

7

Muséum National d'Histoire Naturelle, CNRS UMR 7179, 4 avenue du Petit-Château,

91800 Brunoy (France). E-mail: ponge@mnhn.fr

10

11 (Received July 25, 2007; revised January 29, 2008)

12

ABSTRACT

14

The short-term influence of dung deposition and its further redistribution by dung beetles was studied under a resting place of the red howler monkey (Alouatta seniculus) living in tropical rain forests of South America. Monkey dung was experimentally clumped on the field in a place used by troops of howler monkeys for resting (Nouragues reserve station, French Guiana). Dung-treated plots were sampled serially over three weeks and compared with controls located in their immediate vicinity. The composition of the soil matrix (top $10 \mathrm{~cm}$ ) was studied in successive micro-layers by an optical method. Under the

22 influence of dung beetle activity the topsoil became more homogeneous, losing its litter, its 
1 were penetrated by roots. The results were interpreted to the light of known effects of soil

2 animal activity on plant growth and seedling survival.

4 Key Words:dung beetle activity, earthworm faeces, roots, tropical rain forests

INTRODUCTION

7

In the French Guianan primary rain forest, fruit-eating monkeys, in particular the most common red howler monkeys (Alouatta seniculus L.), defecate in places where troops (ca. 7 individuals each) are resting for night or some time of the day (Julliot, 1996a; Julliot et al., 2001). Resting places are distributed over the whole territory of the troop and are used regularly or occasionally according to seasons (Julliot, 1992). Dung ( 1.5 kg.day ${ }^{-1}$ in each troop) is incorporated in a few hours in the topsoil through the burying activity of flying dung beetles which are olfactorily attracted to smears of fallen monkey faeces (Feer, 1999; Feer and Pincebourde, 2005). By this process the soil is locally enriched in fresh and nutrient-rich organic matter (Feeley, 2005), a sparsely distributed component of the tropical rain forest ecosystem (Cuevas and Medina, 1988; Burghouts et al., 1998; Martius et al., 2004), and in seeds of a variety of trees and lianas with pulp fruits (Julliot and Sabatier, 1993; Julliot, 1996b). As a result, a higher number of seeds and seedlings of forest plant species have been shown to occur under resting places of the howler monkey, thus pointing to the importance of this process for forest regeneration and richness in species (Julliot, 1997; Julliot et al., 2001). The impact of this processing chain (Heard, 1994) on the composition of the topsoil is still unknown. Short- and long-term effects are expected, depending on the frequency with which resting sites are used by troops of howler monkeys. 
The present study, undergone in French Guiana, was focused on the composition of

3 the topsoil and the distribution of humus components (plant debris, roots, animal faeces)

4 following dung deposition by howler monkeys. We selected a place which was used

5 repetitively by the same troop of howler monkeys, a common pattern of their social

6 behaviour (Julliot and Sabatier, 1993). This is a preliminary assessment of the effects of a

7 processing chain involving plants (trees and lianas), vertebrates (monkeys) and

8 invertebrates (dung beetles, soil animals) on soils of the tropical rain forest.

9

We used an optical method, which has been designed for the quantitative analysis

11 of visually recognizable components of the topsoil in temperate (Bernier et al., 1993;

12 Peltier et al., 2001) and tropical (Loranger et al., 2003; Kounda-Kiki et al., 2006) ecosystems.

14

\section{MATERIALS AND METHODS}

16

Study site and sampling procedure

The study site was a resting place used by a troop of howler monkeys, $100 \mathrm{~m}$ from the 'Nouragues' research station (French Guiana, $100 \mathrm{~km}$ south of the Atlantic Coast),

21 which is located within a nature reservation from which human activities (hunting comprised) are excluded, and without any human settlement for several centuries (CharlesDominique, 2001). The soil is a clayey Ferralsol, acid, yellowish, with a microaggregate texture of biological origin, and a sparsely distributed litter cover on the ground floor (Grimaldi and Riéra, 2001). The forest type is the equatorial rain forest, with canopy trees 
1 as high as $50 \mathrm{~m}$ and a sparse understory (Poncy et al., 2001). The annual rainfall averages

$23000 \mathrm{~mm}$, with a short dry season in September and October, and a mean annual 3 temperature of $26.3^{\circ} \mathrm{C}$ (Grimaldi and Riéra, 2001).

4

The site was used by monkeys on 17 April 2004. Excrements were immediately

6 collected then homogenized and grouped into clumps of near equal amount $(\sim 100 \mathrm{~g}$ over 1

$7 \mathrm{dm}^{2}$ ) which were noted D1 to D4, their position being indicated in the field by a stamp, to

8 be retrieved later once dung has disappeared from the ground surface. The soil was

9 sampled at the same places at Day 12, 14, 21 and 23, respectively. Two control samples C1

10 and $\mathrm{C} 2$ were taken in the same site on Day 5 and 11, respectively, in places without any

11 sign of recent defecation.

12

At the centre of each sampling plot, a block of surface soil $25 \mathrm{~cm}^{2}$ in area and 10 cm depth was cut with a sharp knife, with as little disturbance as possible, and litter and soil underneath were carefully sampled. Each humus block was separated into individual layers that could be identified macroscopically on the base of structure, composition and other relevant properties (Kounda-Kiki et al., 2006) or arbitrarily each $\mathrm{cm}$ when the soil was visually homogeneous. The various layers were transferred into polypropylene jars filled with $95 \%$ ethanol before transport to the laboratory. Care was taken that the jars were completely filled with the sampled material in order to avoid changes in structure resulting

21 from shaking during transport to the laboratory.

Microscopical analyses 
All 65 microlayers ( 11 per soil block) were optically studied using the 'small

2 volume' micromorphological method developed by Bernier and Ponge (1994), to which

3 reference is made for details. Results from grid point counting (ca. 400 points) were

4 expressed as the percentage of a given class of litter/humus component. A total of 158

5 classes of litter/humus components were identified (Appendix). The use of an eye reticle

6 allowed to measure the size of organic or mineral particles or assemblages.

7

Plant debris were classified into leaves, cuticle/epidermis, petioles/nerves, stem/wood, bark, seeds, seed coats and according to the size of fragments. Roots and mycorrhizae were separated by colour and diameter in section. Animal faeces were classified by the size, the shape, the degree of mixing of mineral matter with organic matter and their state of transformation and assigned to animal groups using Bal (1982), Ponge (1991) and Topoliantz et al. (2000).

\section{Data analyses}

Percentages of occurrence of classes of litter/humus components in the 65 microlayers investigated were subjected to a correspondence analysis or CA (Greenacre, 1984). The different classes of litter/humus components were the active (main) variables, coded by their percentage of occurrence by volume. These components were classified into 61 gross categories, which were included as passive variables in the analysis.

All variables were transformed into $X=(x-m) / s+20$, where $x$ is the original value, $m$ is the mean of a given variable, and $s$ is its standard deviation (Sadaka and Ponge, 2003). The addition to each standardized variable of a constant factor of 20 allows all values to be 
1 positive, CA dealing only with positive numbers. Factorial coordinates of weighted

2 variables (with constant mean and variance) can be interpreted directly in terms of their

3 contribution to the factorial axes, contrary to raw data (Greenacre, 1984).

4

The volume percent of a given class (or gross category) of litter/humus components

6 can be averaged over the whole profile $(0-10 \mathrm{~cm})$, taking into account the different micro-

7 layers, each individual value being weighted by the thickness of the corresponding microlayer. This allowed to calculate the mean percent volume of the different classes of litter/humus components and of the gross categories in each humus profile (Appendix).

RESULTS

When bulked over the 10 top $\mathrm{cm}$, and when all components were pooled into 11 main gross categories, the composition of the six investigated humus profiles did not vary to a great extent (Fig. 1). In all six sample profiles, the topsoil was mainly made of earthworm mineral faeces, i.e. faeces with a poor content of organic matter given their light colour (Schulze et al., 1993). However, the percentage of earthworm faeces in the top $10 \mathrm{~cm}$ (20 to $40 \%$ ) increased steadily with time from the start of sampling (linear regression, $\left.\mathrm{R}^{2}=0.99, \mathrm{t}=14.1, \mathrm{P}=0.005\right)$, beginning at a level lower than that of control samples. The second most abundant component was roots (20 to 30\%), which did not

21 increase with time but was higher in dung-treated samples than in controls (Mann-

22 Whitney, $\mathrm{U}=4.7, \mathrm{P}<0.0001)$. Earthworm hemorganic faeces were the second most abundant faecal component (7 to $15 \%$ ) and earthworm holorganic faeces were nearly absent $(<1 \%)$. Faeces of other animals (mainly enchytraeids, but also millipedes and 
1 was but poorly represented (5 to $10 \%$ ). Aggregates which could not be attributed to recent

2 faecal deposition amounted to 10 to $30 \%$ of total solids. Over the six studied humus

3 profiles, the distribution of mineral, hemorganic and holorganic categories was similar in

4 aggregates and earthworm faeces $\left(\chi^{2}=0.61, \mathrm{P}=0.74\right)$.

Differences between dung-treated and control samples were much more pronounced in the vertical distribution of topsoil components. The distribution of microlayers and categories of humus components in the plane of the first two axes of CA (Fig. 2) showed that the composition of humus profiles varied according to depth, a complex of factors which was represented by Axis 1 (Fig. 3a). As expected, control samples exhibited a surface composition (see negative values of Axis 1) which contrasted greatly with that of deeper layers (positive values), but this contrast was much less pronounced in dung-treated samples. In control samples, the surface micro-layers were formed of plant material (roots and litter debris) and holorganic faeces (gross categories 32 to 57, all with negative values of Axis 1 , with only a few exceptions) which were but badly represented at the surface of dung-treated samples.

17

Visual examples of the distribution of gross categories of topsoil components are given for root-permeated aggregates and faeces (Fig. 3b), earthworm mineral faeces (Fig. 3c) and root material (Fig. 3d). Root-permeated aggregates and faeces were present at the soil surface in dung-treated places then increased steadily with depth while in control samples they were absent in surface and present in a lesser amount underneath (Fig. 3b). Earthworm mineral faeces increased steadily from surface to deeper layers but they represented up to $30 \%$ of the soil matrix in the top $2 \mathrm{~cm}$ of dung-treated profiles while they were near absent at the same depth level in control samples. Root material (free roots, not 
1 included onto faeces or aggregates) was more abundant at the soil surface and remained

2 higher in content at depth in dung-treated samples than in control soil (Fig. 3d). An

3 increase from 0 to $3-4 \mathrm{~cm}$ followed by a decrease was observed in the vertical distribution

4 of root material in dung-treated samples, while this material decreased steadily in control

5 samples.

6

7 DISCUSSION AND CONCLUSIONS

8

9

The topsoil under resting places of howler monkeys is mainly made of earthworm faeces of varying size and organic matter content, indicating a high level of biological activity through the stimulation of microbial processes and nutrient cycles (Lavelle et al., 1998; Ponge, 2003). This can be compared with the higher level of plant recruitment which has been measured in these places (Julliot, 1997). Dung deposition (including seed of fleshy fruits) is followed by a chain of soil biological processes which embraces the burying action of dung beetles (Feer, 1999), the redistribution of organic and mineral matter by soil animals (Anderson, 1995) and the development of the root system of plants (Feeley, 2005).

When monkey dung is buried into the soil by dung beetles, deeper horizons (down to $40 \mathrm{~cm}$ ) are excavated and pushed up to the surface, where they form small aerated mounds of yellow mineral soil resembling molehills (personal observations). We observed that these mounds, which are not protected by any litter cover, are rapidly flattened by canopy drip and disappear in a few days. Our study, done on the top $10 \mathrm{~cm}$ of soil, showed that the excavated soil, although poor in organic matter (light colour), became extensively colonized by earthworms and by roots within a few weeks (Fig. 1). Control samples did 
1 not show any earthworm faecal material and any penetration of aggregates and faeces by

2 roots in surface layers, while it was the case after dung application (Fig. 3b). The

3 importance of earthworm faeces for the growth of the root system of plants has been

4 observed and experimentally established (Tomati et al., 1988), as well as their favourable

5 role for soil structure (Blanchart, 1992) and water infiltration (Kladivko et al., 1986). To

6 the light of existing literature, it can be suspected that any event which favours earthworm

7 activity will favour (i) the rapid development of the root system of trees and tree seedlings,

8 the latter being of paramount importance for forest regeneration (Julliot et al., 2001), (ii)

9 the alleviation of ground floor toxicity following litter removal (Madge, 1965; Dalling and

10 Hubbell, 2002). It should be noted, too, that seeds of a variety of tree species with fleshy

11 fruits are concentrated in monkey dung (Julliot, 1996b) and that earthworms are known for

12 the vertical redistribution of seed (Willems and Huijsmans, 1994) and their selective action

13 on the soil seed bank (Thompson et al., 1994; Decaëns et al., 2003). All these aspects point

14 to a rapid, positive feed-back involving monkeys, dung beetles and earthworms, favourable

15 to the early and selective establishment of plant seedlings in a restricted array of favourable

16 micro-sites (Harper et al., 1965; Grubb, 1986; Dalling and Hubbell, 2002).

17

ACKNOWLEDGEMENTS

19

20 The authors warmly acknowledge the staff of the Nouragues reserve station (CNRS,

21 Guyane) for accomodation and field assistance. 
1

2

3

4

6

7

8

9

10

11

12 3

\section{REFERENCES}

(

Anderson, J.M. 1995. Soil organisms as engineers: microsite modulation of macroscale processes. In Jones, C.G. and Lawton, J.H. (eds.) Linking Species and Ecosystems. Chapman and Hall, London, pp. 94-106.

Bal, L. 1982. Zoological Ripening of Soils. Pudoc, Wageningen. 365 pp.

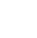

Bernier, N. and Ponge, J.F. 1994. Humus form dynamics during the sylvogenetic cycle in a mountain spruce forest. Soil Biology and Biochemistry. 26: 183-220.

Bernier, N., Ponge, J.F. and André, J. 1993. Comparative study of soil organic layers in two bilberry-psruce forest stands (Vaccinio-Piceetea). Relation to forest dynamics. Geoderma. 59: 89-108.

Blanchart, E. 1992. Restoration by earthworms (Megascolecidae) of the macroagrgegate structure of a destructured savanna soil under field conditions. Soil Biology and Biochemistry. 24: 1587-1594.

Burghouts, T.B.A., Van Straalen, N.M. and Bruijnzeel, L.A. 1998. Spatial heterogeneity of element and litter turnover in a Bornean rain forest. Journal of Tropical Ecology. 14: $477-506$. 
1 Charles-Dominique, P. 2001. The field station. In Bongers, F. et al. (eds.) Nouragues: Dordrecht, pp. 1-7.

Cuevas, E. and Medina, E. 1988. Nutrient dynamics within Amazonian forests. II. Fine root growth, nuttrient availability and leaf litter decomposition. Oecologia. 76: 222235.

Dalling, J.W. and Hubbell, S.P. 2002. Seed size, growth rate and gap microsite conditions as determinants of recruitment success for pioneer species. Journal of Ecology. 90: $557-568$.

Decaëns, T., Mariani, L., Betancourt, N. and Jiménez, J.J. 2003. Seed dispersion by surface casting activities of earthworms in Colombian grasslands. Acta Oecologica. 24: 175-185.

Feeley, K. 2005. The role of clumped defection in the spatial distribution of soil nutrients and the availability of nutrients for plant uptake. Journal of Tropical Ecology. 21: 99-102.

Feer, F. 1999. Effects of dung beetles (Scarabaeidae) on seeds dispersed by howler monkeys (Alouatta seniculus) in the French Guianan rain forest. Journal of Tropical Ecology. 15: 129-142. 
1 Feer, F. and Pincebourde, S. 2005. Diel flight activity and ecological segregation within an assemblage of tropical forest dung and carrion beetles. Journal of Tropical Ecology 21: $21-30$.

Greenacre, M. J. 1984. Theory and Applications of Correspondence Analysis. Academic Press, London. 364 pp.

Grimaldi, M. and Riéra, B. 2001. Geography and climate. In Bongers, F. et al. (eds.) Nouragues: Dynamics and Plant-Animal Interactions in a Neotropical Rainforest. Kluwer, Dordrecht, pp. 9-18.

Grubb, P.J. 1986. The ecology of establishment. In Bradshaw, A.D. et al. (Eds.) Ecology and Design in Landscape. Blackwell, Oxford, pp. 93-97.

Harper, J.L., Williams, J.T. and Sagar, G.R. 1965. The behaviour of seeds in soil. I. The heterogeneity of soil surfaces and its role in determining the establishment of plants from seed. Journal of Ecology. 53: 273-286.

Heard, S.B. 1994. Processing chain ecology: resource condition and interspecific interactions. Journal of Animal Ecology. 63: 451-464.

Julliot, C. 1992. Utilisation des ressources alimentaires par le singe hurleur roux, Alouatta seniculus (Atelidae, Primates), en Guyane: impact de la dissémination des graines sur la régénération forestière. Unpublished PhD Thesis, University of Tours, France. 
2 Julliot, C. 1996a. Seed dispersal by red howler monkeys (Alouatta seniculus) in the tropical rain forest of French Guiana. International Journal of Primatology. 17: 239-258.

Julliot, C. 1996b. Fruit choice by red howler monkeys (Alouatta seniculus) in a tropical 7 rain forest. American Journal of Primatology. 40: 261-282.

Julliot, C. 1997. Impact of seed dispersal by red howler monkeys Alouatta seniculus on the seedling population in the understorey of tropical rain forest. Journal of Ecology. 85: $431-440$.

12

Julliot, C. and Sabatier, D. 1993. Diet of the red howler monkey (Alouiatta seniculus) in French Guiana. International Journal of Primatology 14: 527-550.

Julliot, C., Simmen, B. and Zhang, S. 2001. Frugivory and seed dispersal by three neotropical primates: impact on plant regeneration. In Bongers, F. et al. (eds.) Nouragues: Dynamics and Plant-Animal Interactions in a Neotropical Rainforest. Kluwer, Dordrecht, pp. 197-205.

Kladivko, E.J., Mackay, A.D. and Bradford, J.M. 1986. Earthworms as a factor in the reduction of soil crusting. Soil Science Society of America Journal. 50: 191-196. 
1 Kounda-Kiki, C., Vaçulik, A., Ponge, J.F. and Sarthou, C. 2006. Humus profiles under main vegetation types in a rock savanna (Nouragues inselberg, French Guiana). Geoderma. 136: 819-829.

Lavelle, P., Pashanasi, B., Charpentier, F., Gilot, C., Rossi, J.P., Derouard, L., André, J., Ponge, J.F. and Bernier, N. 1998. Large-scale effects of earthworms on soil organic matter and nutrient dynamics. In Edwards, C.A. (ed.) Earthworm Ecology. Saint Lucie Press, Boca Raton, pp. 103-122.

Loranger, G., Ponge, J.F. and Lavelle, P. 2003. Humus forms in two secondary semievergreen tropical forests. European Journal of Soil Science. 54: 17-24.

Madge, D.S. 1965. Leaf fall and litter disappearance in a tropical forest. Pedobiologia. 5: 273-288.

Martius, C., Höfer, H., Garcia, M.V.B., Römke, J. and Hanagarth, W. 2004. Litter fall, litter stocks and decomposition rates in rainforest and agroforestry sites in central Amazonia. Nutrient Cycling in Agroecosystems. 68: 137-154.

Peltier, A., Ponge, J.F., Jordana, R. and Ariño, A. 2001. Humus forms in Mediterranean scrublands with aleppo pine. Soil Science Society of America Journal. 65: 884-896.

Poncy, O., Sabatier, D., Prévost, M.F. and Hardy, I. 2001. The lowland high rainforest: structure and tree species diversity. In Bongers, F. et al. (eds.) Nouragues: 
Ponge, J.F. 1991. Food resources and diets of soil animals in a small area of Scots pine litter. Geoderma. 49: 33-62.

Ponge, J.F. 2003. Humus forms in terrestrial ecosystems: a framework to biodiversity. Soil Biology and Biochemistry. 35: 935-945.

Sadaka, N. and Ponge, J.F. 2003. Climatic effects on soil trophic networks and the resulting humus profiles in holm oak (Quercus rotundifolia) forests in the high Atlas of Morocco as revealed by correspondence analysis. European Journal of Soil Science. 54: 767-777.

Schulze, D.G., Nagel, J.L., Van Scoyoe, G.E., Henderson, T.L., Baumgardner, M.F. and Stott, D.E. 1993. Significance of organic matter in determining soil colors. Soil Science Society of America Special Publication. 31: 71-90.

Thompson, K., Green, A. and Jewels, A.M. 1994. Seeds in soil and worm casts from a neutral grassland. Functional Ecology. 8: 29-35.

Tomati, U., Grappelli, A. and Galli, E. 1988. The hormone-like effect of earthworm casts on plant growth. Biology and Fertility of Soils. 5: 288-294. 
1 Topoliantz, S., Ponge J. F. and Viaux, P. 2000. Earthworm and enchytraeid activity under different arable farming systems, as exemplified by biogenic structures. Plant and 3 Soil. 225: 39-51.

4

5 Willems, J.H. and Huijsmans, K.G.A. 1994. Vertical seed dispersal by earthworms: a 6 quantitative approach. Ecography. 17: 124-130.

7 


\section{Figure captions}

2

3 Fig. 1. Composition in percent volume (gross categories) of the soil matrix in the top 10

4 $\mathrm{cm}$ of the six studied samples (D1 to D4 = dung-treated samples at Days 12, 14, 21 and 23; $\mathrm{C} 1$ and $\mathrm{C} 2=$ control samples)

6

7 Fig. 2. Projection of main categories (added as passive variables) and micro-layers of the six studied samples in the plane of the first two axes of CA (correspondence analysis). Codes of categories as in Appendix

Fig. 3. (a) Vertical distribution of Axis 1 values (CA)

(b) Vertical distribution of root-permeated faeces and aggregates

(c) Vertical distribution of earthworm mineral faeces

14

(d) Vertical distribution of roots 


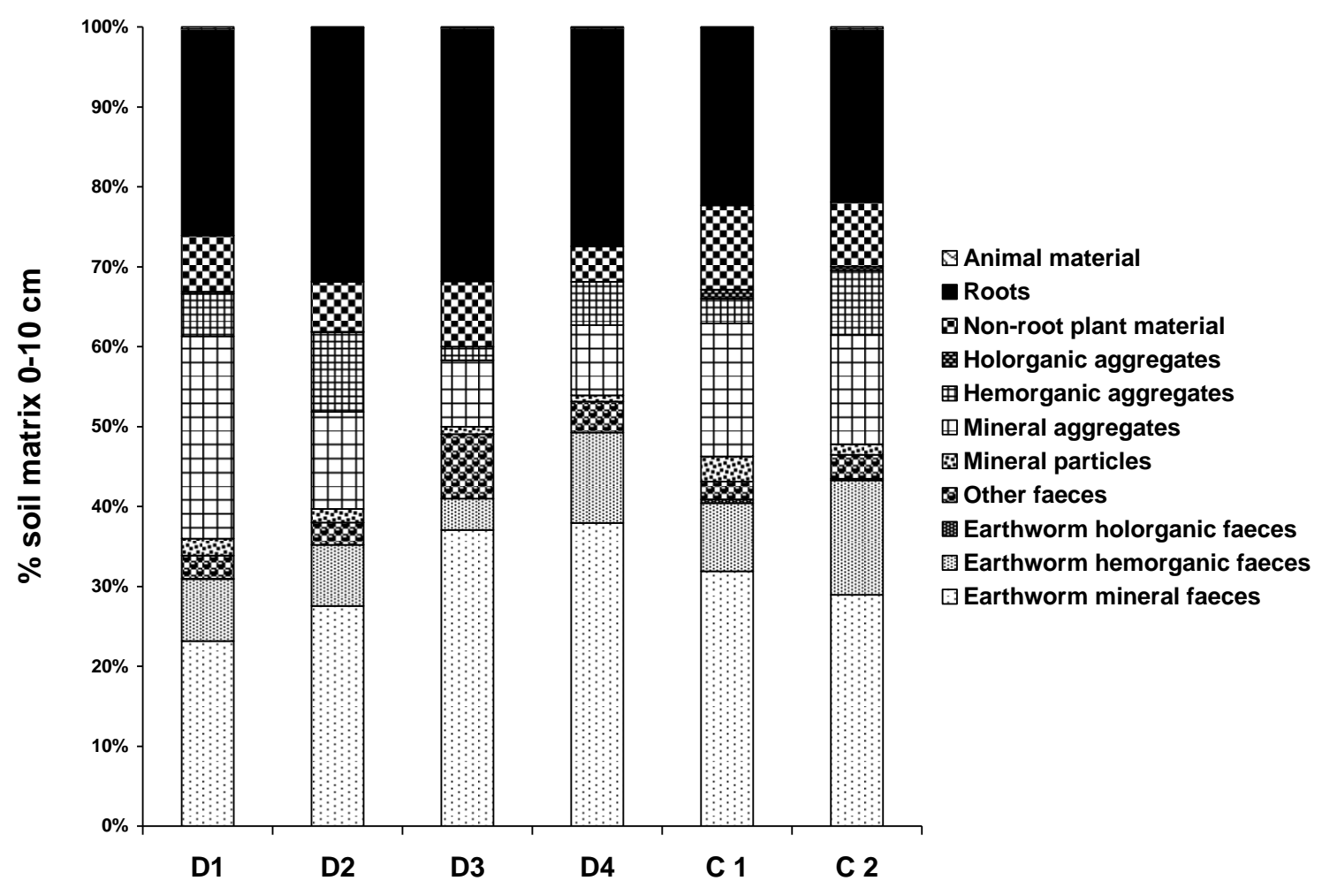

2 Fig. 1 


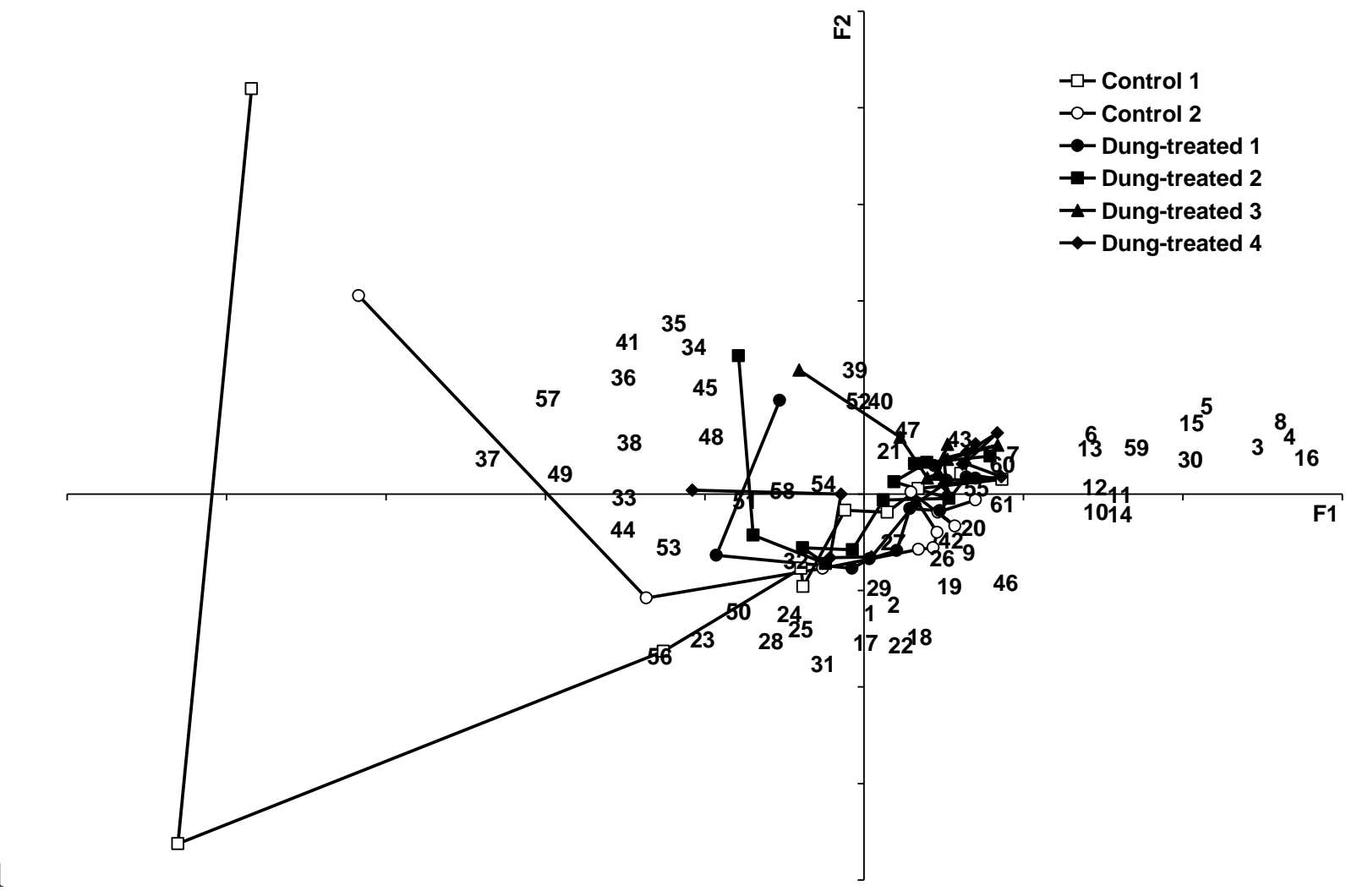

Fig. 2 
1
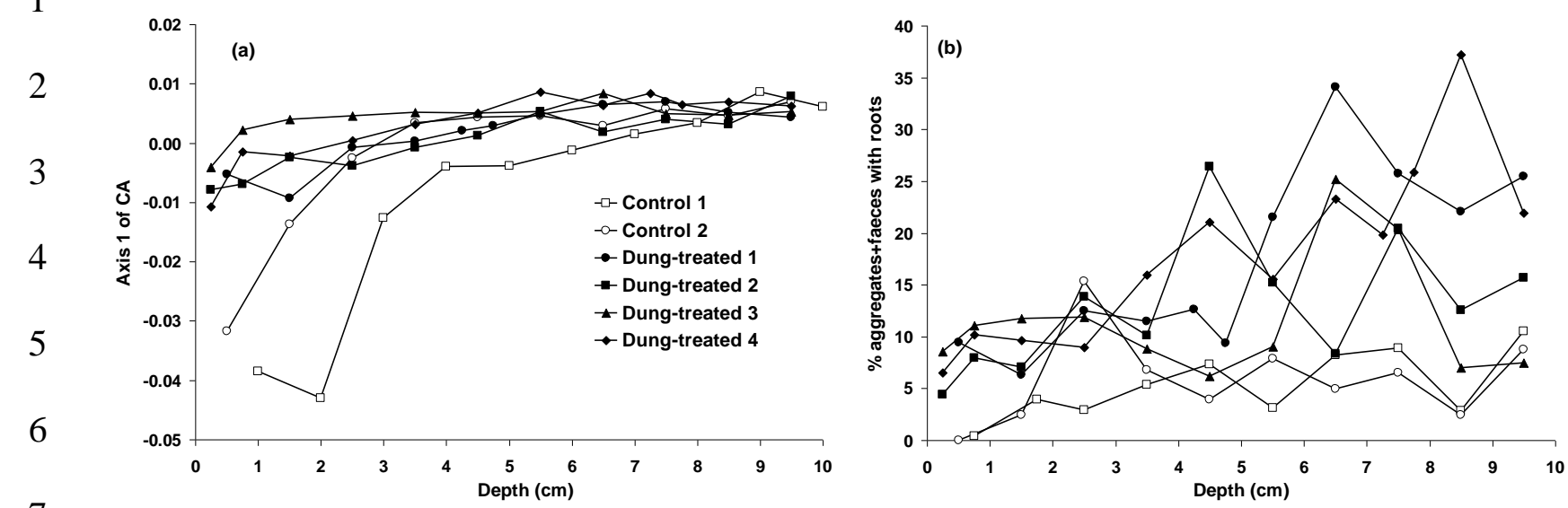

7
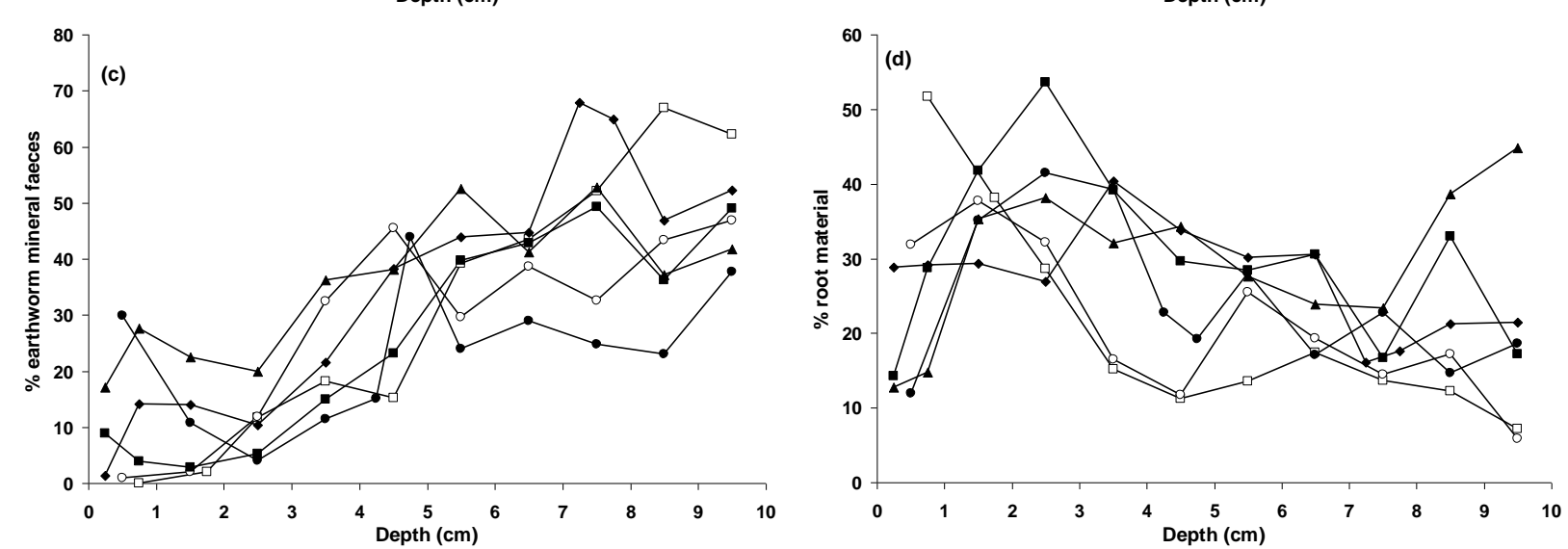

13 Fig. 3.

14 
Appendix. List of categories identified in the soil matrix under the dissecting microscope, together with their mean percent volume and coordinates along Axis 1 of correspondence analysis

\begin{tabular}{|c|c|c|c|c|c|c|c|c|}
\hline Code & Categories & D1 & D2 & D3 & D4 & C1 & C2 & Axis 1 (CA) \\
\hline & Quartz particle 0-1 mm & 1.08 & 0.50 & 0.49 & 0.74 & 2.79 & 0.87 & -0.003 \\
\hline & Quartz particle 1-2 mm & 0.61 & 0.50 & 0.42 & 0.05 & 0.14 & 0.19 & 0.011 \\
\hline & Quartz particle $>2 \mathrm{~mm}$ & 0.00 & 0.19 & 0.00 & 0.00 & 0.00 & 0.05 & 0.009 \\
\hline & Laterite particle & 0.34 & 0.47 & 0.00 & 0.05 & 0.15 & 0.20 & 0.007 \\
\hline \multirow[t]{74}{*}{59} & Enchytraeid faeces & 2.73 & 2.69 & 7.51 & 4.20 & 2.15 & 2.16 & 0.017 \\
\hline & Earthworm mineral faeces $<1 \mathrm{~mm}$ & 3.95 & 4.13 & 3.56 & 4.60 & 6.95 & 5.33 & 0.018 \\
\hline & Earthworm mineral faeces $1-2 \mathrm{~mm}$ intact & 2.11 & 1.94 & 1.87 & 2.05 & 2.74 & 2.94 & 0.017 \\
\hline & Earthworm mineral faeces $1-2 \mathrm{~mm}$ enchytraeid-tunnelled & 2.36 & 5.05 & 5.01 & 4.36 & 2.18 & 1.54 & 0.022 \\
\hline & Earthworm mineral faeces $2-5 \mathrm{~mm}$ intact & 0.86 & 0.62 & 1.50 & 1.13 & 1.70 & 2.58 & 0.015 \\
\hline & Earthworm mineral faeces $2-5 \mathrm{~mm}$ root-permeated & 0.07 & 0.02 & 0.20 & 0.17 & 0.00 & 0.00 & 0.009 \\
\hline & Earthworm mineral faeces 2-5 mm enchytraeid-tunnelled & 7.04 & 7.18 & 11.59 & 11.75 & 9.26 & 7.57 & 0.026 \\
\hline & Earthworm mineral faeces $2-5 \mathrm{~mm}$ root-permeated enchytraeid-tunnelled & 1.59 & 1.59 & 1.42 & 2.17 & 0.43 & 0.19 & 0.018 \\
\hline & Earthworm mineral faeces 5-10 mm intact & 0.00 & 0.07 & 0.17 & 0.00 & 0.23 & 0.45 & 0.006 \\
\hline & Earthworm mineral faeces 5-10 $\mathrm{mm}$ root-permeated & 0.00 & 0.00 & 0.10 & 0.00 & 0.00 & 0.00 & 0.007 \\
\hline & Earthworm mineral faeces 5-10 mm enchytraeid-tunnelled & 1.96 & 3.24 & 5.33 & 4.75 & 5.85 & 5.75 & 0.019 \\
\hline & Earthworm mineral faeces 5-10 mm root-permeated enchytraeid-tunnelled & 1.67 & 2.16 & 3.51 & 3.50 & 1.04 & 0.63 & 0.019 \\
\hline & Earthworm mineral faeces $10-15 \mathrm{~mm}$ enchytraeid-tunnelled & 0.10 & 0.00 & 0.43 & 0.87 & 0.18 & 1.36 & 0.011 \\
\hline & Earthworm mineral faeces $10-15 \mathrm{~mm}$ root-permeated enchytraeid-tunnelled & 0.35 & 0.98 & 1.22 & 2.82 & 0.43 & 0.05 & 0.013 \\
\hline & Earthworm mineral faeces $>15 \mathrm{~mm}$ intact & 0.34 & 0.00 & 0.00 & 0.00 & 0.00 & 0.00 & 0.001 \\
\hline & Earthworm mineral faeces $>15 \mathrm{~mm}$ enchytraeid-tunnelled & 0.00 & 0.00 & 0.00 & 0.57 & 0.00 & 0.00 & 0.008 \\
\hline & Earthworm mineral faeces $>15 \mathrm{~mm}$ root-permeated enchytraeid-tunnelled & 0.00 & 0.00 & 0.55 & 2.51 & 0.00 & 0.00 & 0.010 \\
\hline & Mineral aggregate $<1 \mathrm{~mm}$ & 2.50 & 0.91 & 0.49 & 1.62 & 2.78 & 0.72 & 0.002 \\
\hline & Mineral aggregate $1-2 \mathrm{~mm}$ intact & 0.22 & 0.00 & 0.00 & 0.17 & 0.88 & 0.14 & -0.008 \\
\hline & Mineral aggregate 1-2 mm enchytraeid-tunnelled & 1.67 & 1.06 & 1.14 & 0.75 & 0.47 & 0.29 & 0.012 \\
\hline & Mineral aggregate $2-5 \mathrm{~mm}$ intact & 0.05 & 0.05 & 0.00 & 0.10 & 0.68 & 0.09 & -0.011 \\
\hline & Mineral aggregate $2-5 \mathrm{~mm}$ root-permeated & 0.00 & 0.00 & 0.00 & 0.00 & 0.10 & 0.00 & 0.002 \\
\hline & Mineral aggregate 2-5 mm enchytraeid-tunnelled & 3.72 & 2.82 & 1.80 & 1.27 & 2.88 & 2.93 & 0.016 \\
\hline & Mineral aggregate 2-5 mm root-permeated enchytraeid-tunnelled & 2.31 & 0.62 & 0.47 & 0.43 & 0.19 & 0.33 & 0.013 \\
\hline & Mineral aggregate $5-10 \mathrm{~mm}$ intact & 0.05 & 0.00 & 0.00 & 0.00 & 0.22 & 0.00 & -0.007 \\
\hline & Mineral aggregate 5-10 mm root-permeated & 0.00 & 0.00 & 0.00 & 0.00 & 0.02 & 0.00 & -0.013 \\
\hline & Mineral aggregate 5-10 mm enchytraeid-tunnelled & 2.98 & 1.84 & 1.11 & 0.63 & 3.91 & 4.02 & 0.015 \\
\hline & Mineral aggregate 5-10 mm root-permeated enchytraeid-tunnelled & 4.82 & 1.56 & 1.10 & 1.32 & 0.67 & 0.53 & 0.014 \\
\hline & Mineral aggregate $10-15 \mathrm{~mm}$ intact & 0.00 & 0.00 & 0.00 & 0.00 & 0.30 & 0.00 & -0.012 \\
\hline & Mineral aggregate $10-15 \mathrm{~mm}$ root-permeated & 0.00 & 0.00 & 0.00 & 0.00 & 0.02 & 0.00 & -0.013 \\
\hline & Mineral aggregate $10-15 \mathrm{~mm}$ enchytraeid-tunnelled & 0.49 & 0.71 & 0.15 & 0.00 & 1.33 & 2.49 & 0.012 \\
\hline & Mineral aggregate $10-15 \mathrm{~mm}$ root-permeated enchytraeid-tunnelled & 3.09 & 1.38 & 0.87 & 1.36 & 1.06 & 1.19 & 0.014 \\
\hline & Mineral aggregate $>15 \mathrm{~mm}$ enchytraeid-tunnelled & 0.49 & 0.00 & 0.00 & 0.20 & 0.38 & 0.67 & 0.012 \\
\hline & Mineral aggregate $>15 \mathrm{~mm}$ root-permeated enchytraeid-tunnelled & 2.09 & 0.97 & 1.11 & 1.69 & 0.29 & 0.00 & 0.012 \\
\hline & Earthworm hemorganic faeces $<1 \mathrm{~mm}$ & 0.85 & 0.45 & 0.31 & 0.26 & 0.68 & 1.31 & -0.002 \\
\hline & Earthworm hemorganic faeces $1-2 \mathrm{~mm}$ intact & 0.95 & 0.65 & 0.30 & 0.89 & 1.28 & 2.19 & -0.002 \\
\hline & Earthworm hemorganic faeces 1-2 mm enchytraeid-tunnelled & 0.68 & 0.84 & 0.35 & 0.43 & 0.24 & 0.92 & 0.005 \\
\hline & Earthworm hemorganic faeces $2-5 \mathrm{~mm}$ intact & 0.73 & 0.43 & 0.57 & 0.38 & 0.63 & 1.76 & 0.000 \\
\hline & Earthworm hemorganic faeces $2-5 \mathrm{~mm}$ root-permeated & 0.00 & 0.00 & 0.00 & 0.19 & 0.00 & 0.20 & 0.004 \\
\hline & Earthworm hemorganic faeces $2-5 \mathrm{~mm}$ enchytraeid-tunnelled & 2.32 & 2.87 & 0.99 & 3.24 & 3.09 & 4.48 & 0.004 \\
\hline & Earthworm hemorganic faeces $2-5 \mathrm{~mm}$ root-permeated enchytraeid-tunnelled & 0.29 & 0.29 & 0.05 & 1.05 & 0.14 & 0.10 & 0.007 \\
\hline & Earthworm hemorganic faeces $5-10 \mathrm{~mm}$ intact & 0.05 & 0.00 & 0.20 & 0.14 & 0.09 & 0.10 & 0.007 \\
\hline & Earthworm hemorganic faeces $5-10 \mathrm{~mm}$ root-permeated & 0.00 & 0.00 & 0.00 & 0.00 & 0.06 & 0.00 & -0.011 \\
\hline & Earthworm hemorganic faeces 5-10 mm enchytraeid-tunnelled & 0.89 & 0.83 & 0.59 & 3.28 & 1.67 & 2.08 & 0.006 \\
\hline & Earthworm hemorganic faeces 5-10 mm root-permeated enchytraeid-tunnelled & 0.61 & 0.78 & 0.24 & 0.89 & 0.14 & 0.39 & 0.004 \\
\hline & Earthworm hemorganic faeces $10-15 \mathrm{~mm}$ intact & 0.00 & 0.00 & 0.00 & 0.00 & 0.05 & 0.00 & -0.013 \\
\hline & Earthworm hemorganic faeces $10-15 \mathrm{~mm}$ enchytraeid-tunnelled & 0.00 & 0.10 & 0.00 & 0.59 & 0.19 & 0.24 & 0.003 \\
\hline & Earthworm hemorganic faeces $10-15 \mathrm{~mm}$ root-permeated enchytraeid-tunnelled & 0.10 & 0.14 & 0.10 & 0.95 & 0.00 & 0.24 & 0.010 \\
\hline & Earthworm hemorganic faeces $>15 \mathrm{~mm}$ root-permeated enchytraeid-tunnelled & 0.00 & 0.12 & 0.19 & 0.00 & 0.00 & 0.00 & 0.002 \\
\hline & Hemorganic aggregate $<1 \mathrm{~mm}$ & 1.18 & 1.05 & 0.02 & 1.22 & 0.53 & 0.93 & -0.005 \\
\hline & Hemorganic aggregate $1-2 \mathrm{~mm}$ intact & 0.44 & 0.33 & 0.00 & 0.45 & 0.27 & 0.48 & -0.015 \\
\hline & Hemorganic aggregate 1-2 mm enchytraeid-tunnelled & 0.90 & 0.89 & 0.12 & 0.33 & 0.24 & 0.29 & 0.000 \\
\hline & Hemorganic aggregate $2-5 \mathrm{~mm}$ intact & 0.05 & 0.14 & 0.00 & 0.21 & 0.27 & 0.20 & -0.013 \\
\hline & Hemorganic aggregate $2-5 \mathrm{~mm}$ root-permeated & 0.10 & 0.00 & 0.00 & 0.00 & 0.02 & 0.05 & -0.008 \\
\hline & Hemorganic aggregate $2-5 \mathrm{~mm}$ enchytraeid-tunnelled & 1.18 & 2.79 & 0.17 & 0.95 & 0.39 & 1.84 & 0.000 \\
\hline & Hemorganic aggregate $2-5 \mathrm{~mm}$ root-permeated enchytraeid-tunnelled & 0.22 & 1.03 & 0.00 & 0.40 & 0.00 & 0.20 & 0.000 \\
\hline & Hemorganic aggregate $5-10 \mathrm{~mm}$ intact & 0.00 & 0.00 & 0.00 & 0.00 & 0.20 & 0.00 & -0.013 \\
\hline & Hemorganic aggregate $5-10 \mathrm{~mm}$ root-permeated & 0.00 & 0.00 & 0.00 & 0.00 & 0.12 & 0.00 & -0.013 \\
\hline & Hemorganic aggregate $5-10 \mathrm{~mm}$ enchytraeid-tunnelled & 0.15 & 1.35 & 0.29 & 0.87 & 0.49 & 1.40 & 0.004 \\
\hline & Hemorganic aggregate 5-10 mm root-permeated enchytraeid-tunnelled & 0.46 & 1.02 & 0.31 & 0.52 & 0.15 & 0.63 & 0.004 \\
\hline & Hemorganic aggregate $10-15 \mathrm{~mm}$ enchytraeid-tunnelled & 0.25 & 0.12 & 0.42 & 0.14 & 0.00 & 0.71 & 0.007 \\
\hline & Hemorganic aggregate $10-15 \mathrm{~mm}$ root-permeated enchytraeid-tunnelled & 0.20 & 0.58 & 0.33 & 0.80 & 0.29 & 0.54 & 0.004 \\
\hline & Hemorganic aggregate $>15 \mathrm{~mm}$ root-permeated & 0.00 & 0.00 & 0.00 & 0.00 & 0.00 & 0.54 & 0.004 \\
\hline & Hemorganic aggregate $>15 \mathrm{~mm}$ enchytraeid-tunnelled & 0.00 & 0.14 & 0.00 & 0.00 & 0.00 & 0.00 & 0.004 \\
\hline & Hemorganic aggregate $>15 \mathrm{~mm}$ root-permeated enchytraeid-tunnelled & 0.00 & 0.33 & 0.00 & 0.00 & 0.00 & 0.10 & 0.001 \\
\hline & Earthworm holorganic faeces $<1 \mathrm{~mm}$ & 0.00 & 0.00 & 0.00 & 0.00 & 0.05 & 0.05 & 0.001 \\
\hline & Earthworm holorganic faeces $1-2 \mathrm{~mm}$ & 0.00 & 0.00 & 0.00 & 0.00 & 0.05 & 0.00 & 0.003 \\
\hline & Earthworm holorganic faeces $2-5 \mathrm{~mm}$ & 0.00 & 0.00 & 0.00 & 0.00 & 0.24 & 0.09 & -0.001 \\
\hline & Earthworm holorganic faeces 5-10 mm & 0.05 & 0.00 & 0.00 & 0.00 & 0.10 & 0.05 & -0.004 \\
\hline & Holorganic aggregate $<1 \mathrm{~mm}$ & 0.00 & 0.00 & 0.00 & 0.02 & 0.22 & 0.05 & -0.006 \\
\hline & Holorganic aggregate $1-2 \mathrm{~mm}$ & 0.10 & 0.00 & 0.00 & 0.00 & 0.17 & 0.00 & -0.005 \\
\hline & Holorganic aggregate $2-5 \mathrm{~mm}$ & 0.10 & 0.05 & 0.00 & 0.00 & 0.40 & 0.15 & -0.016 \\
\hline & Holorganic aggregate 5-10 mm & 0.05 & 0.00 & 0.00 & 0.00 & 0.29 & 0.20 & -0.008 \\
\hline & Holorganic aggregate $10-15 \mathrm{~mm}$ & 0.00 & 0.00 & 0.00 & 0.00 & 0.06 & 0.10 & 0.000 \\
\hline 60 & Millipede faeces & 0.09 & 0.00 & 0.40 & 0.00 & 0.00 & 0.00 & 0.009 \\
\hline \multirow[t]{4}{*}{61} & Termite faeces & 0.00 & 0.00 & 0.00 & 0.00 & 0.00 & 0.77 & 0.009 \\
\hline & Leaf fragment $<2 \mathrm{~mm}$ & 0.05 & 0.10 & 0.14 & 0.35 & 0.06 & 0.13 & -0.006 \\
\hline & Leaf fragment 2-5 mm & 0.94 & 0.39 & 0.48 & 0.76 & 0.87 & 0.60 & -0.015 \\
\hline & Leaf fragment $5-10 \mathrm{~mm}$ & 0.89 & 0.34 & 0.47 & 0.49 & 1.48 & 0.82 & -0.016 \\
\hline
\end{tabular}


Leaf fragment $>10 \mathrm{~mm}$

Cuticle/epidermis fragment $<2 \mathrm{~mm}$

Cuticle/epidermis fragment $2-5 \mathrm{~mm}$

Cuticle/epidermis fragment 5-10 mm

Petiole/nerve fragment $<2 \mathrm{~mm}$

Petiole/nerve fragment $2-5 \mathrm{~mm}$

Petiole/nerve fragment $5-10 \mathrm{~mm}$

Petiole/nerve fragment $>10 \mathrm{~mm}$

Stem/wood fragment $<2 \mathrm{~mm}$

Stem/wood fragment $2-5 \mathrm{~mm}$

Stem/wood fragment $5-10 \mathrm{~mm}$

Stem/wood fragment $>10 \mathrm{~mm}$

Bark fragment $<2 \mathrm{~mm}$

Bark fragment 2-5 mm

Bark fragment 5-10 mm

Bark fragment $>10 \mathrm{~mm}$

Seed coat fragment $<2 \mathrm{~mm}$

Seed coat fragment $2-5 \mathrm{~mm}$

Seed coat fragment 5-10 mm

Seed coat fragment $>10 \mathrm{~mm}$

Seed $<2 \mathrm{~mm}$

Seed $2-5 \mathrm{~mm}$

Seed $5-10 \mathrm{~mm}$

Seed $>10 \mathrm{~mm}$

Club moss (Selaginella)

Mycelium

Black rhizomorph

White rhizomorph

Miscellaneous (humified or unidentified) plant material

Charcoal

Fruit fragment

Bud

Black root $\varnothing<0.5 \mathrm{~mm}$

Black root $\varnothing 0.5-1 \mathrm{~mm}$

Black root $\varnothing 1-2 \mathrm{~mm}$

Brown root $\varnothing<0.5 \mathrm{~mm}$

Brown root $\varnothing 0.5-1 \mathrm{~mm}$

Brown root $\varnothing 1-2 \mathrm{~mm}$

Brown root $\varnothing>2 \mathrm{~mm}$

Beaded root $\varnothing<0.5 \mathrm{~mm}$

Beaded root $\varnothing 0.5-1 \mathrm{~mm}$

Beaded root $\varnothing 1-2 \mathrm{~mm}$

Beaded root $\varnothing>2 \mathrm{~mm}$

Detached bead (from beaded root)

Red root $\varnothing<0.5 \mathrm{~mm}$

Red root $\varnothing 0.5-1 \mathrm{~mm}$

Red root $\varnothing 1-2 \mathrm{~mm}$

Light-brown root $\varnothing<0.5 \mathrm{~mm}$

Light-brown root $\varnothing 0.5-1 \mathrm{~mm}$

Light-brown root $\varnothing 1-2 \mathrm{~mm}$

Light-brown root $\varnothing>2 \mathrm{~mm}$

White root $\varnothing<0.5 \mathrm{~mm}$

White root $\varnothing 0.5-1 \mathrm{~mm}$

White root $\varnothing 1-2 \mathrm{~mm}$

White root with hairs $\varnothing<0.5 \mathrm{~mm}$

White root with hairs $\varnothing 0.5-1 \mathrm{~mm}$

White root with hairs $\varnothing 1-2 \mathrm{~mm}$

White root with hairs $\varnothing>2 \mathrm{~mm}$

Root with claret-coloured mycorrhizae $\varnothing<0.5 \mathrm{~mm}$

Root with claret-coloured mycorrhizae $\varnothing 0.5-1 \mathrm{~mm}$

Root with claret-coloured mycorrhizae $\varnothing 1-2 \mathrm{~mm}$

Root with claret-coloured mycorrhizae $\varnothing>2 \mathrm{~mm}$

Root with orange mycorrhizae $\varnothing<0.5 \mathrm{~mm}$

Root with orange mycorrhizae $\varnothing 0.5-1 \mathrm{~mm}$

Root with orange mycorrhizae $\varnothing 1-2 \mathrm{~mm}$

Root fragment

Voided root $\varnothing<0.5 \mathrm{~mm}$

Voided root $\varnothing 0.5-1 \mathrm{~mm}$

Voided root $\varnothing 1-2 \mathrm{~mm}$

Root fibers

Potworm (Enchytraeida)

Insect larva

Arthropod cuticle

Arthropod

Total quartz particles

Total earthworm mineral faeces $1-2 \mathrm{~mm}$

Total earthworm mineral faeces $2-5 \mathrm{~mm}$

Total earthworm mineral faeces $5-10 \mathrm{~mm}$

Total earthworm mineral faeces $10-15 \mathrm{~mm}$

Total earthworm mineral faeces $>15 \mathrm{~mm}$

Total earthworm mineral faeces

Total mineral aggregates 1-2 mm

Total mineral aggregates $2-5 \mathrm{~mm}$

Total mineral aggregates $5-10 \mathrm{~mm}$

Total mineral aggegates $5-10 \mathrm{~mm}$

Total mineral aggregates $>15 \mathrm{~mm}$

Total mineral aggregates $>15$

Total mineral aggregates with roots

Total mineral material

17 Total earthworm hemorganic faeces $1-2 \mathrm{~mm}$

\begin{tabular}{|c|c|c|c|c|c|c|}
\hline 0.50 & 1.77 & 1.11 & 0.49 & 0.83 & 1.04 & -0.005 \\
\hline 0.05 & 0.21 & 0.02 & 0.07 & 0.02 & 0.04 & -0.007 \\
\hline 0.00 & 0.14 & 0.02 & 0.05 & 0.19 & 0.00 & -0.008 \\
\hline 0.00 & 0.00 & 0.00 & 0.00 & 0.13 & 0.00 & -0.011 \\
\hline 0.05 & 0.02 & 0.00 & 0.00 & 0.31 & 0.00 & -0.020 \\
\hline 0.35 & 0.02 & 0.00 & 0.02 & 0.24 & 0.00 & -0.004 \\
\hline 0.10 & 0.05 & 0.00 & 0.00 & 0.13 & 0.04 & -0.010 \\
\hline 0.05 & 0.00 & 0.00 & 0.12 & 0.00 & 0.18 & -0.008 \\
\hline 0.00 & 0.02 & 0.26 & 0.00 & 0.53 & 0.51 & -0.018 \\
\hline 0.29 & 0.02 & 0.07 & 0.00 & 1.05 & 0.22 & -0.021 \\
\hline 0.05 & 0.00 & 0.15 & 0.00 & 0.00 & 0.04 & 0.001 \\
\hline 0.00 & 0.15 & 0.00 & 0.28 & 0.06 & 0.10 & -0.002 \\
\hline 0.98 & 1.00 & 1.32 & 0.94 & 1.55 & 0.48 & 0.002 \\
\hline 0.66 & 0.70 & 0.94 & 0.55 & 1.56 & 1.52 & -0.016 \\
\hline 0.05 & 0.19 & 0.38 & 0.26 & 0.58 & 0.88 & -0.014 \\
\hline 0.05 & 0.00 & 0.05 & 0.02 & 0.00 & 1.12 & -0.008 \\
\hline 0.00 & 0.00 & 0.00 & 0.00 & 0.06 & 0.00 & -0.011 \\
\hline 0.00 & 0.12 & 0.26 & 0.00 & 0.06 & 0.00 & 0.001 \\
\hline 0.05 & 0.00 & 0.35 & 0.09 & 0.00 & 0.00 & 0.006 \\
\hline 0.00 & 0.05 & 1.14 & 0.24 & 0.50 & 0.18 & -0.001 \\
\hline 0.00 & 0.02 & 0.02 & 0.00 & 0.00 & 0.00 & 0.001 \\
\hline 0.10 & 0.00 & 0.00 & 0.00 & 0.00 & 0.00 & 0.002 \\
\hline 0.00 & 0.02 & 0.14 & 0.05 & 0.00 & 0.00 & 0.006 \\
\hline 1.59 & 0.71 & 0.70 & 0.00 & 0.00 & 0.00 & 0.001 \\
\hline 0.00 & 0.00 & 0.00 & 0.02 & 0.13 & 0.04 & -0.014 \\
\hline 0.05 & 0.00 & 0.07 & 0.00 & 0.05 & 0.05 & 0.003 \\
\hline 0.07 & 0.02 & 0.02 & 0.05 & 0.17 & 0.05 & -0.004 \\
\hline 0.05 & 0.02 & 0.00 & 0.00 & 0.20 & 0.09 & -0.019 \\
\hline 2.07 & 0.80 & 0.26 & 0.72 & 0.55 & 0.99 & -0.007 \\
\hline 0.05 & 0.10 & 0.23 & 0.09 & 0.00 & 0.00 & 0.004 \\
\hline 0.02 & 0.05 & 0.19 & 0.00 & 0.24 & 0.00 & 0.011 \\
\hline 0.00 & 0.00 & 0.00 & 0.00 & 0.05 & 0.00 & -0.001 \\
\hline 0.05 & 0.07 & 0.23 & 0.00 & 0.05 & 0.09 & 0.005 \\
\hline 0.15 & 0.19 & 0.57 & 0.07 & 0.20 & 0.76 & 0.004 \\
\hline 0.05 & 0.17 & 0.57 & 0.00 & 0.00 & 0.86 & 0.006 \\
\hline 4.28 & 6.92 & 6.91 & 7.60 & 5.19 & 0.77 & 0.002 \\
\hline 7.22 & 6.97 & 4.93 & 8.10 & 3.02 & 2.35 & 0.002 \\
\hline 2.54 & 3.99 & 6.06 & 4.90 & 1.57 & 0.88 & 0.007 \\
\hline 1.31 & 3.59 & 10.37 & 3.02 & 0.29 & 0.63 & 0.010 \\
\hline 0.02 & 0.16 & 0.00 & 0.00 & 0.57 & 0.00 & -0.006 \\
\hline 1.15 & 2.96 & 0.23 & 0.86 & 2.39 & 2.63 & -0.016 \\
\hline 1.07 & 1.46 & 0.14 & 0.45 & 0.72 & 3.09 & -0.010 \\
\hline 0.10 & 0.00 & 0.00 & 0.00 & 0.20 & 1.90 & -0.005 \\
\hline 0.49 & 0.84 & 0.23 & 0.22 & 0.27 & 0.78 & -0.002 \\
\hline 0.02 & 0.05 & 0.00 & 0.00 & 0.25 & 0.05 & -0.010 \\
\hline 0.00 & 0.33 & 0.19 & 0.00 & 0.10 & 0.73 & -0.006 \\
\hline 0.00 & 0.19 & 0.00 & 0.00 & 0.05 & 0.27 & -0.007 \\
\hline 3.06 & 1.35 & 0.05 & 0.96 & 0.33 & 1.50 & 0.011 \\
\hline 1.40 & 0.87 & 0.05 & 1.46 & 1.19 & 1.99 & 0.004 \\
\hline 0.50 & 0.05 & 0.00 & 0.10 & 0.33 & 0.58 & 0.009 \\
\hline 0.00 & 0.00 & 0.00 & 0.00 & 0.29 & 0.00 & 0.005 \\
\hline 0.86 & 0.17 & 0.24 & 0.89 & 0.66 & 0.39 & 0.000 \\
\hline 0.00 & 0.05 & 0.14 & 0.40 & 0.00 & 0.10 & 0.010 \\
\hline 0.05 & 0.00 & 0.00 & 0.00 & 0.00 & 0.00 & 0.007 \\
\hline 0.05 & 0.07 & 0.00 & 0.00 & 0.11 & 0.24 & -0.002 \\
\hline 0.00 & 0.00 & 0.00 & 0.00 & 0.00 & 0.36 & -0.009 \\
\hline 0.00 & 0.00 & 0.00 & 0.00 & 0.00 & 0.09 & -0.009 \\
\hline 0.00 & 0.00 & 0.00 & 0.00 & 0.00 & 0.04 & -0.009 \\
\hline 0.00 & 0.10 & 0.00 & 0.00 & 0.51 & 0.00 & -0.011 \\
\hline 0.15 & 0.14 & 0.00 & 0.00 & 1.81 & 0.00 & -0.016 \\
\hline 0.05 & 0.00 & 0.00 & 0.00 & 0.13 & 0.00 & -0.011 \\
\hline 0.00 & 0.00 & 0.00 & 0.00 & 0.20 & 0.00 & -0.010 \\
\hline 0.00 & 0.00 & 0.00 & 0.09 & 0.00 & 0.00 & 0.010 \\
\hline 0.00 & 0.00 & 0.00 & 0.34 & 0.22 & 0.00 & -0.010 \\
\hline 0.00 & 0.00 & 0.00 & 0.14 & 0.00 & 0.00 & 0.010 \\
\hline 0.42 & 0.45 & 0.26 & 0.05 & 0.91 & 0.14 & -0.006 \\
\hline 0.10 & 0.14 & 0.05 & 0.02 & 0.27 & 0.09 & -0.011 \\
\hline 0.59 & 0.57 & 0.10 & 0.00 & 0.89 & 0.49 & -0.013 \\
\hline 0.07 & 0.00 & 0.19 & 0.02 & 0.15 & 0.15 & 0.005 \\
\hline 0.27 & 0.33 & 0.47 & 0.41 & 0.19 & 0.05 & 0.009 \\
\hline 0.00 & 0.00 & 0.00 & 0.05 & 0.00 & 0.00 & 0.007 \\
\hline 0.00 & 0.00 & 0.09 & 0.14 & 0.00 & 0.00 & 0.004 \\
\hline 0.00 & 0.00 & 0.00 & 0.00 & 0.00 & 0.04 & -0.009 \\
\hline 0.24 & 0.10 & 0.07 & 0.00 & 0.10 & 0.18 & 0.000 \\
\hline 0.00 & 0.00 & 0.00 & 0.00 & 0.02 & 0.00 & -0.013 \\
\hline 1.69 & 1.20 & 0.91 & 0.79 & 2.93 & 1.11 & 0.000 \\
\hline 2.04 & 1.67 & 0.91 & 0.84 & 3.08 & 1.31 & 0.002 \\
\hline 4.47 & 6.98 & 6.88 & 6.41 & 4.92 & 4.48 & 0.025 \\
\hline 9.56 & 9.41 & 14.71 & 15.20 & 11.39 & 10.35 & 0.027 \\
\hline 3.63 & 5.47 & 9.11 & 8.25 & 7.12 & 6.82 & 0.021 \\
\hline 0.44 & 0.98 & 1.66 & 3.69 & 0.61 & 1.41 & 0.014 \\
\hline 0.34 & 0.00 & 0.55 & 3.07 & 0.00 & 0.00 & 0.009 \\
\hline 22.40 & 26.98 & 36.47 & 41.23 & 30.99 & 28.38 & 0.027 \\
\hline 1.89 & 1.06 & 1.14 & 0.92 & 1.35 & 0.43 & 0.007 \\
\hline 6.08 & 3.49 & 2.26 & 1.79 & 3.84 & 3.35 & 0.015 \\
\hline 7.85 & 3.40 & 2.20 & 1.95 & 4.82 & 4.55 & 0.016 \\
\hline 3.58 & 2.09 & 1.02 & 1.36 & 2.71 & 3.68 & 0.014 \\
\hline 2.59 & 0.97 & 1.11 & 1.89 & 0.66 & 0.67 & 0.014 \\
\hline 24.49 & 11.93 & 8.22 & 9.53 & 16.16 & 13.40 & 0.016 \\
\hline 15.99 & 9.29 & 10.54 & 15.96 & 4.25 & 2.93 & 0.021 \\
\hline 51.65 & 43.27 & 53.11 & 55.80 & 52.39 & 45.26 & 0.028 \\
\hline 1.64 & 1.49 & 0.66 & 1.32 & 1.52 & 3.11 & 0.000 \\
\hline
\end{tabular}


18 Total earthworm hemorganic faeces $2-5 \mathrm{~mm}$

Total earthworm hemorganic faeces $5-10 \mathrm{~mm}$

Total earthworm hemorganic faeces $10-15 \mathrm{~mm}$

Total earthworm hemorganic faeces $>15 \mathrm{~mm}$

Total earthworm hemorganic faeces

Total hemorganic aggregates $1-2 \mathrm{~mm}$

Total hemorganic aggregates $2-5 \mathrm{~mm}$

Total hemorganic aggregates $5-10 \mathrm{~mm}$

Total hemorganic aggregates $10-15 \mathrm{~mm}$

Total hemorganic aggregates $>15 \mathrm{~mm}$

Total hemorganic aggregates

Total hemorganic aggregates with roots

Total aggregates with roots

Total hemorganic material

Total earthworm holorganic faeces

Total holorganic aggregates

Total leaf fragments

Total cuticle/epidermis fragments

Total petiole/nerve fragments

Total stem/wood fragments

Total bark fragments

Total seed coat fragments

Total seeds

Total non-root plant material

Total black roots

Total brown roots

Total beaded roots

Total red roots

Total light-brown roots

Total white roots

Total white roots with hairs

Total roots with claret-coloured mycorrhizae

Total roots with orange mycorrhizae

Total roots

Total roots $\varnothing<0.5 \mathrm{~mm}$

Total roots $\varnothing 0.5-1 \mathrm{~mm}$

Total roots $\varnothing 1-2 \mathrm{~mm}$

Total roots $\varnothing>2 \mathrm{~mm}$

Total voided roots

Total plant material

\begin{tabular}{lllllll}
3.34 & 3.60 & 1.61 & 4.86 & 3.87 & 6.53 & 0.003 \\
1.55 & 1.62 & 1.02 & 4.31 & 1.97 & 2.57 & 0.005 \\
0.10 & 0.24 & 0.10 & 1.55 & 0.24 & 0.48 & 0.006 \\
0.00 & 0.12 & 0.19 & 0.00 & 0.00 & 0.00 & 0.002 \\
7.47 & 7.52 & 3.88 & 12.30 & 8.28 & 14.00 & 0.002 \\
1.34 & 1.22 & 0.12 & 0.78 & 0.51 & 0.77 & -0.010 \\
1.54 & 3.96 & 0.17 & 1.56 & 0.68 & 2.28 & -0.005 \\
0.61 & 2.38 & 0.60 & 1.39 & 0.96 & 2.02 & -0.004 \\
0.45 & 0.70 & 0.75 & 0.95 & 0.29 & 1.25 & 0.005 \\
0.00 & 0.48 & 0.00 & 0.00 & 0.00 & 0.64 & 0.002 \\
5.12 & 9.78 & 1.66 & 5.90 & 2.98 & 7.90 & -0.006 \\
1.98 & 4.30 & 1.22 & 4.81 & 0.94 & 2.98 & 0.001 \\
17.97 & 13.59 & 11.76 & 20.77 & 5.19 & 5.91 & 0.020 \\
12.59 & 17.30 & 5.54 & 18.20 & 11.26 & 21.90 & -0.003 \\
0.05 & 0.00 & 0.00 & 0.00 & 0.43 & 0.19 & -0.004 \\
0.24 & 0.05 & 0.00 & 0.02 & 1.13 & 0.49 & -0.015 \\
2.38 & 2.61 & 2.20 & 2.09 & 3.25 & 2.60 & -0.011 \\
0.05 & 0.36 & 0.05 & 0.12 & 0.34 & 0.04 & -0.012 \\
0.55 & 0.10 & 0.00 & 0.14 & 0.67 & 0.22 & -0.015 \\
0.34 & 0.20 & 0.48 & 0.28 & 1.64 & 0.88 & -0.024 \\
1.73 & 1.90 & 2.68 & 1.78 & 3.70 & 4.00 & -0.015 \\
0.05 & 0.17 & 1.75 & 0.33 & 0.63 & 0.18 & -0.001 \\
1.69 & 0.76 & 0.86 & 0.05 & 0.00 & 0.00 & 0.001 \\
6.79 & 6.09 & 8.03 & 4.79 & 10.22 & 7.92 & -0.015 \\
0.25 & 0.43 & 1.37 & 0.07 & 0.24 & 1.71 & 0.005 \\
15.36 & 21.48 & 28.27 & 23.61 & 10.07 & 4.62 & 0.006 \\
2.84 & 5.43 & 0.60 & 1.53 & 4.16 & 8.41 & -0.015 \\
0.02 & 0.57 & 0.19 & 0.00 & 0.39 & 1.05 & -0.010 \\
4.95 & 2.27 & 0.10 & 2.52 & 2.14 & 4.08 & 0.009 \\
0.91 & 0.21 & 0.38 & 1.30 & 0.66 & 0.49 & 0.003 \\
0.05 & 0.07 & 0.00 & 0.00 & 0.11 & 0.74 & -0.010 \\
0.20 & 0.24 & 0.00 & 0.00 & 2.64 & 0.00 & -0.019 \\
0.00 & 0.00 & 0.00 & 0.57 & 0.22 & 0.00 & -0.008 \\
25.00 & 31.15 & 31.18 & 29.65 & 21.56 & 21.23 & -0.007 \\
8.35 & 8.89 & 7.44 & 9.54 & 7.68 & 3.04 & 0.000 \\
10.07 & 11.52 & 6.11 & 11.23 & 8.93 & 8.93 & -0.012 \\
4.26 & 5.85 & 6.76 & 5.59 & 2.80 & 5.77 & -0.003 \\
1.41 & 3.59 & 10.37 & 3.02 & 0.97 & 2.57 & 0.007 \\
0.76 & 0.71 & 0.33 & 0.05 & 1.30 & 0.73 & -0.013 \\
34.90 & 39.14 & 40.46 & 35.65 & 34.24 & 30.96 & -0.020 \\
0.24 & 0.10 & 0.16 & 0.19 & 0.12 & 0.23 & -0.005 \\
\hline & & & & & & \\
& & & & & & \\
0.515 &
\end{tabular}

